\title{
THE IMPLEMENTATION OF INFORMATION AND COMMUNICATTION TECHNOLOGIES INTO MUSIC EDUCATION
}

Jarmila $\check{S} I \check{R} I C K A$ *, Univerzita Palackého v Olomouci, Česká republika

Přijato: 15. 4. 2018 / Akceptováno: 24. 10. 2018

Typ článku: Výzkumná studie

DOI: $10.5507 /$ jtie.2018.009

Abstract: The article deals with the new trends in music education. It evaluates the current situation by analyzing the level and ways of ICT usage in music education at Czech schools focusing on finding and exploring the possibilities of ICT and mobile technologies usage as a means of support of the creativity and cooperation of students as well as the motivating element in music education. It informs the reader about some musical activities using ICT done as a pilot training, and also the reaction of the pupils to them.

Key words: ICT literacy, mobile technology, touch device, upgrade of education, music education, creativity, competence, motivation, evaluation, cooperation and activity of pupils.

\section{IMPLEMENTACE INFORMAČNÍCH A KOMUNIKAČNÍCH TECHNOLOGIÍ DO HUDEBNÍ VÝCHOVY}

Abstrakt: Článek se zabývá novými trendy ve výuce hudební výchovy. Hodnotí současný stav zjištěním míry a způsobu využití ICT v hudební výchově na českých školách, zaměruje se na hledání a zkoumání možnosti využití ICT a mobilnich technologii jako prostředku podpory žákovské kreativity a kooperace i jako prvku motivačního v edukačním procesu hudebni výchovy. Seznamuje čtenářre s některými hudebními aktivitami využivajícími ICT, které proběhly pilotni výukou, a také reakcí žákü na ně.

Klíčová slova: ICT gramotnost, mobilní technologie, dotyková zařízení, modernizace výuky, hudební výchova, kreativita, kompetence, motivace, kooperace a aktivizace žáků.

\footnotetext{
*Autor pro korespondenci: jarmila.siricka@upol.cz
} 


\section{1 Úvod}

Současným trendem školství na všech jeho úrovních je hledání a zavádění nových učebních strategií s cílem zlepšit kvalitu vzdělávání. Digitalizace učebních materiálů a smysluplná implementace moderních prostředků informačních a komunikačních technologií (ICT) do př́mého procesu edukace je jednou z možných cest. Většina výzkumných dokumenti̊ zaměřujících se na podobnou tématiku zkoumá využití ICT z hlediska přípravy na výukovou jednotku. V hudební výchově (dále jen HV) jde především o zkoumání práce učitele při použití notačních programů a softwarů v přípravě výukových materiálů, jak se zmiňovali ve své prací např. tito autoři: M. Vávra Aplikace hudebního softwaru Ableton Live v hudebni edukaci, O. Musil Multimediálná výuka HV nebo M. Waltová Využití hudebního softwaru v didaktické praxi učitele hudební nauky. Výzkum je zaměřen na modernizaci HV v přímé výuce, objektem zkoumání jsou ICT užité ve většině jejích kategorií. Cílem výzkumu je hledání nových možností využití ICT ve výuce HV a posouzení efektivity výuky s implementací ICT ve srovnání s tradičními postupy. Důležitou součástí práce je ověření několika následujících hypotéz:

- prostřednictvím užití ICT se zvýší motivace žáka kaktivitě v hudebních činnostech;

- $\quad$ zvýší se žákovská participace na hudebním vzdělávání;

- $\quad$ zvýší se atraktivita výuky HV;

- $\quad$ zvýší se úspěšnost žáka při testování.

Součástí výzkumu je také zjištění míry spokojenosti žáků i učitelů s těmito postupy výuky.

\section{Inovativní tendence výuky hudební výchovy}

Učitelé z praxe chtějí modernizovat výuku svých předmětů. Důkazem je velká návštěvnost portálů jako např. www.rvp.cz, www.ceskaskola, www.dumy.cz a také množství vzniklých a stále nově vznikajících výukových materiálů s prvky inovačních trendů ve vzdělávání (digitalizace materiálů, interaktivní tabule, tablety, ...).

Tyto portály učitelé využívají pro vzájemné sdílení zkušeností i materiálů z výuky, případně umožňují materiály sdílet i svým žákům. K nalezení je mnoho inspirativních materiálů. Nutno také konstatovat, že část těchto DUMů (digitálních učebních materiálů) sice prokazuje hudební znalosti tvůrců a jejich technické dovednosti při práci s ICT, ale mnohé z nich nejsou z didaktického hlediska dle mého názoru dobře zpracované. Zejména PowerPointové prezentace, které jsou spíše souhrnem informací, většinou postrádají hudebně - výchovné prvky či prvky interaktivity (otázky k zamyšlení, otázky k diskusi, drobné úkoly, pracovní listy). Míra atraktivity edukačních prostř̌edků pak může převýšit míru splnění výukových cílů. $\mathrm{V}$ inovativním procesu své místo nalézají také interaktivní učebnice napřr. učebnice nakladatelství Fraus, Nová škola či euroDIDACT. Významnou roli pro sdílení zkušeností z výuky má také využití webových stránek veřejných či soukromých, sociálních sítí a dalších virtuálních prostředí. Pro moderní výuku hudební výchovy nelze neprripomenout i inspirativní metodický blog s videonávody a odkazy paní Lenky Pobudové http://jaknahudebku.blogspot.cz/.

Předchozí část reflektovala popis ICT užitých při vzájemné spolupráci mezi učiteli. Předmětem našeho zájmu je ovšem využití ICT především během běžné školní praxe, v interakci učitel - žák či žáci mezi sebou.

Jestliže mají ICT posílit edukační proces, neměly by být používány pouze jako projekční nástroj. Má-li být užití informačních a komunikačních technologií v přímém 
procesu výuky smysluplné a účelné, dle Průchy (1997, str. 307) mělo by splňovat tyto charakteristiky:

a) užívání interaktivních prostředků pro předávání informací v obousměrné komunikaci;

b) kombinované informace, obsahující obraz, zvuk, klasickou písemnou informaci;

c) víceúrovňová informace, obsahující možnost postupovat $\mathrm{v}$ textu různými směry (hypertext).

Jan Průcha (1997, str. 324) také použivá pojem komunikační ostýchavost. Každé dítě touží po úspěchu, ale strach z nezdaru či posměchu spolužáků právě při hudebních činnostech mnohé děti při jejich výkonu svazuje či omezuje. ICT může přinést možnost změnit edukační prostředí a vytvořit bezpečné podmínky pro úspěšné splnění úkolu i pro tyto žáky (viz níže - záznam kreativní hudebně - pohybové činnosti).

Dalš́ autor - Yves Bertrand (1998, str. 103) charakterizuje infomační technologie jako zajímavý nástroj vzdělávání, který usnadňuje mimo jiné interaktivní integraci rozmanitých medií a snazší prrístup $\mathrm{k}$ poznatkům $\mathrm{v}$ přirozeném jazyce $\mathrm{i} v$ grafickém vyjádření a kooperativní užívání poznatků.

Z těchto charakteristik také vychází podoba zkoumaných nových výukových materiálů, které mají za úkol podpořit nejen hudebně - kognitivní činnosti žáků, ale také žákovskou kooperaci a participaci v edukačním procesu HV.

\section{Popis výzkumu}

Cíl práce bude dosažen pomocí kvantitativního výzkumu s prvky výzkumu kvalitativního. Výzkum je rozdělen do několika částí:

1) zjištění míry a způsobu využití ICT v HV - dotazníkové šetření s uzavřenými otázkami s možností zápisu doplňujících informací;

2) prríprava a ověření digitálních učebních materiálů a pracovních listů s interaktivními činnostmi;

3) pilotní výuka s pozorováním;

4) kvalitativní výzkum - dotazníkové šetření (míra spokojenosti využití ICT pohledem učitele i žáka);

5) kvantitativní výzkum - experimentální metoda (porovnání edukace s využitím ICT a bez ní);

6) statistické zpracování dat.

\section{Průzkum míry a způsobu využití ICT v HV}

Sběr dat pro první část výzkumu proběhl dotazníkovým šetřením v roce 2016. Dotazník byl rozeslán elektronicky na základní školy a gymnázia v České republice. Osloveno bylo 721 respondentů (vyučujících hudební výchovu). Návratnost byla 131, toto číslo odpovídá $18,2 \%$ celkově dotazovaných. Cílem této části výzkumu bylo zjistit jaká je vybavenost učitelů hudební výchovy ICT prvky a pomůckami, jejich využití v hodinách v souvislosti $\mathrm{s}$ hudebními $\mathrm{i}$ výukovými činnostmi a také $\mathrm{v}$ př́pravě na výukovou jednotku z pozice učitele i žáka. Získaná data byla též vyhodnocena ve vztahu $\mathrm{k}$ věku, pohlaví a aprobovanosti učitelů. $Z$ analýzy výzkumu plyne, že učitelé všech typů škol, věkových kategorií i všech možností aprobací se snaží prvky ICT využívat (viz Obrázek č. 1). Téměř 70 \% dotazovaných odpovědělo, že ICT využívá v každé hodině, velmi často nebo často. Zbývajících 30 \% dotazovaných ICT při výuce užívá jen občas nebo je nevyuživá. Dalším předmětem zájmu bylo zastoupení ICT ve všech kategoriích hudebních činností. Dle předpokladu nejčastější užití zaznamenaly poslechové činnosti, v hodnocení četnosti je 
následují pohybové a vokální činnosti (viz Obrázek č. 2). Překvapivé je vyšší procento užití ICT při podpoře kreativní činnosti žáků. V malé míře se užívají prvky ICT i pro př́mou komunikaci učitele se žákem.

Dříve mnoho př́strojů v učebně mohlo znamenat jistou finanční zátěž. Většinu přístrojů dnes nahrazují dokonalé funkce počítačů, notebooků a mobilních zařízení. Univerzálnost jejich použití je zřejmá. V průzkumném šetření 67,9 \% respondentů odpovědělo, že tablet nemá $\mathrm{k}$ dispozici. Dle našeho názoru, ale využití právě tohoto zařízení či tzv. „,chytrého telefonu“ má pro hudební výchovu velký potenciál a dává možnost jeho maximálního využití. Jejich multifunkčnost (multimediální zdroj informací, alternativa hudebního nástroje, komunikační nástroj, záznam činností) dává možnost hledat inovativní či alternativní postupy při využití těchto zařízení při výuce.

\section{Četnost užití ICT při výuce HV}

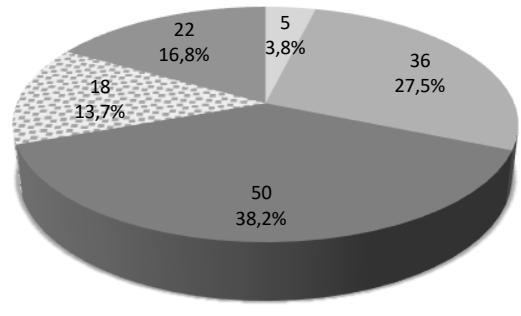

nevyužívám - 5

využívám občas - 36

využívám často -50

využívám velmi často -18

využívám v každé hodině - 22

Obr. č. 1: Využití ICT ve výuce $H V$

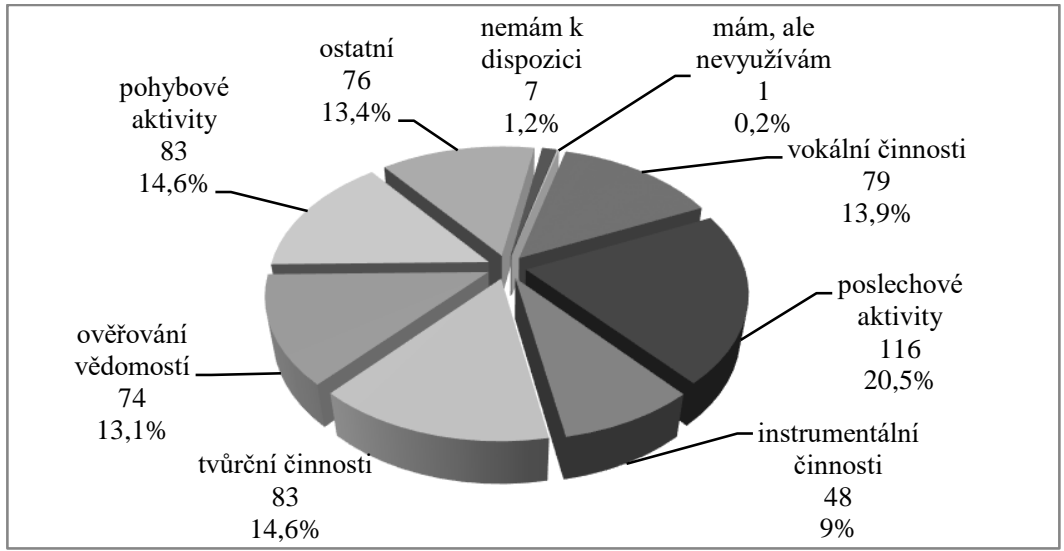

Obr. č. 2: Využití počitače při hudebnich činnostech 


\section{Pilotní výuka s implementací ICT do hudebních aktivit}

Pilotní výuka ověřovala průběh inovovaných hudebních aktivit s implementací ICT, nové digitální učební materiály a pracovní listy s interaktivními prvky. Účastnili se jí žáci druhého stupně vzdělávání na FZŠ Hálkova Olomouc. Před zahájením pilotáže proběhlo ověření technických možností žáků a školy a následné zajištění dalšího potřebného technického zázemí výzkumu. Příprava pokračovala tvorbou materiálů určených k výzkumu. Zaměřili jsme se na využití dotykových zařízení při hudebních činnostech během výuky. Užití moderních technologií, obzvlášt' vlastních žákovských zařízení, pohledem vyučující činilo učební jednotky žákům atraktivnější. Tato skutečnost se projevila zvýšenou participací „nehudebních žákư“ na výuce a také jejich zvýšenou aktivitou. Jevila se též podpora kooperace žáků při edukační činnosti.

Při pilotních hodinách hudební výchovy byly užity prvky ICT různým způsobem:

1) alternativní způsob testování či rychlá evaluace výuky s využitím dotykových zařízení ( Kahoot, Moodle);

2) záznam zpracování kreativního skupinového úkolu - videodokumentace a následný rozbor;

3) samostatná či skupinová práce při poslechových aktivitách a při instrumentálních činnostech (užití dotykových zařízení, počítačů a sluchátek, intonační či rytmický výcvik, vizualizace hudby - grafické zpracování hudby, pohyblivá partitura);

4) užití QR kódů př̀i tvorbě interaktivních výukových materiálů.

Evaluace vědomostí - prostréednictvím hlasovacího či dotykového zařízení žáci pracovali s motivačními i prověřovacími testy v prostředí Moodle a Kahoot. Použito bylo testů $\mathrm{s}$ otázkami s možností výběru odpovědi. V př́ípravné fázi výzkumu žáci jevili zvýšený zájem o tuto činnost. Oblíbenější jsou testy tvořené na stránkách Kahoot. Otázkou je, zda kvůli alternativnímu zpo̊sobu provedení testování, či kvůli touze být úspěšný při veřejné prezentaci výsledků testu. Předpokladem je, že po užití tohoto výukového postupu zůstanou vědomosti (dovednosti) žáků trvalejší. Tato hypotéza se ověřuje na dalších výzkumných vzorcích (žáci jiných tříd a škol).

Videozáznam kreativní hudebně - pohybové aktivity - individuální nebo skupinová tvorba, při které se děti snaží komunikovat pomocí vlastního hudebního projevu. Vede k lepšímu porozumění skladatelských sdělení a pochopení pojmu hudebně výrazové prostředky. Změna edukačního prostředí (děti dostanou prostor zdárně a klidně splnit zadaný úkol mimo školu s pořízením videozáznamu výkonu, což jistě ocení především ostýchavé děti, či žáci se specifickými potřebami učení, zejména žáci $\mathrm{s}$ autistickými rysy) dává možnost individuálního př́stupu $\mathrm{k}$ žákům a jeví se jako vhodná alternativa pro splnění zadaného úkolu. Aktivita žáků při samotném plnění úkolů byla zřejmější, což potvrdily i doplňující informace žáků z pilotního výzkumu:

žák $1:$, ...nemusel jsem se bát, že se mi budou spolužáci smát.“

žák $2:$, ,..mnohem méně jsem se styděl...“

žák 3 : ,, mohli jsme vybrat ten nejlepší‘“

Sociální klima třídy má jednoznačně vliv na průběh hudebních činností i na volbu postupů plnění zadaných úkolů. Citlivě vedená aktivita může být nápomocná při budování pozitivních sociálních vztahů mezi žáky. Tabulka č. 1 uvádí pomocí bodového hodnocení preference zvolených postupů při plnění úkolů. Pro hodnocení aktivity žáci udělovali body $1-5$, které určily pořadí volby způsobu řešení úkolu, a to od nejlepší varianty po nejhorší. Otázka byla mířena na samostatnou hudebně - pohybovou aktivitu 
a výběr způsobu řešení měl zajistit nejlepší výkon žáka. Těchto aktivit během roku proběhlo několik, žáci si mohli vyzkoušet různé způsoby řešení a pak je $v$ jednom dotazníku hodnotili. Výsledky šetření ukazují, že ve všech skupinách je jednoznačná preference prezentace úkolu pomocí videozáznamu pouze před učitelem, následovaná osobní prezentací pouze před učitelem. Další pořadí je ovlivněno klimatem třídy. Ve třídě $\mathrm{s}$ bezpečnějším klimatem je další možnou volbou př́má prezentace před kolektivem, ve trrídě $\mathrm{s}$ horším třídním klimatem žáci raději volí opět videozáznam. Preference použití videozáznamu při plnění úkolu nabízí možnost jeho častějšího využití.

Instrumentální hra - využití pohyblivé partitury př̀i harmonickém či rytmickém doprovodu skladeb, usnadnění hry na boomwhackery či jiné nástroje (možnost využití mobilních zař́zení). $\mathrm{V}$ pilotní fázi byla znát zřejmá radost dětí z instrumentální hry bez znalosti notopisu a rytmu. Pohyblivá partitura umožnuje žáky rychleji zapojit do instrumentálních činností a dát jim možnost být součástí tř́ídního orchestru. Tuto skutečnost ocenili zvláště žáci s poruchami učení, pro které tyto aktivity bývají náročné. Je nutné ověřit spokojenost a provést srovnání s užitím běžné partitury a nástrojů, také zjistit zda tato aktivita působí jako motivační prvek k doplnění znalostí.

Využití QR kódů - pomocník v přípravě interaktivních materiálů. Vznikly pro žáky atraktivní vizuální i audio hudební hádanky a pracovní listy pro aktivní poslechové činnosti. V př́ipravné fázi byl zřejmý zájem žáků o tuto činnost, plnili dobrovolné úkoly (př́prava vlastních hudebních hádanek, práce $\mathrm{s}$ vybranou hudební ukázkou). Touto činností bylo podpořeno kooperativní chování žáků. Při práci s pracovním listem byla zřejmá vy̌šši žákovská participace v edukačním procesu, kvalitnější hudební percepce připravených skladeb a snaha o samostatné plnění připravených úkolů.

Z doplňkových informací $\mathrm{v}$ žákovských dotaznících vzešla i žádost o další využití školního prostředí Moodlu a Edookitu pro vyvěšení dalších materiálů (noty, kvízy, instrumentální a rytmické doprovody, prezentace, texty písní).

\begin{tabular}{|c|c|c|c|}
\hline $\begin{array}{l}\text { Poznámka: } \\
\text { Č́sla oznacuuji součt bodủ udèlovaných preferencí } \\
\text { (žák mohl udedlit } 1-5 \text { bodú). }\end{array}$ & $\begin{array}{l}\text { Pilotní } \\
\text { skupina } \\
\text { (14 respondentú) }\end{array}$ & $\begin{array}{l}\text { Výzkumný } \\
\text { vzorek 1 } \\
\text { (26 respondentů) }\end{array}$ & $\begin{array}{l}\text { Výzkumný } \\
\text { vzorek } 2 \\
\text { (26 respondentů) }\end{array}$ \\
\hline $\begin{array}{l}\text { a) osobní prezentace před } \\
\text { třídou bez záznamu }\end{array}$ & 38 & 65 & 87 \\
\hline $\begin{array}{l}\text { b) osobní prezentace před } \\
\text { tř́ídou s videozáznamem }\end{array}$ & 47 & 73 & 98 \\
\hline $\begin{array}{c}\text { prezentace videozáznamu } \\
\text { před tř́ídou }\end{array}$ & 41 & 61 & 92 \\
\hline $\begin{array}{c}\text { d) osobní prezentace pouze } \\
\text { před učitelem }\end{array}$ & 33 & 50 & 54 \\
\hline
\end{tabular}




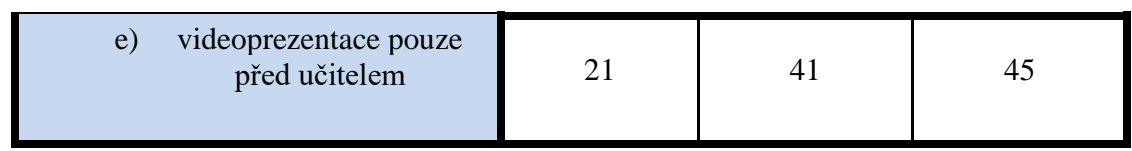

Tab. č. 1: Preference užití videozáznamu při hudebně - pohybové činnosti

\section{Výzkumná perspektiva - hodnocení efektivity a spokojenosti s využitím ICT v hodinách}

V současné době probíhá formou dotazníku sběr dat, který sleduje:

1) spokojenost s výukou s využitím IT pohledem žáka

Akcent je kladen především na:

- náročnost zvládnutí IT při výuce;

- časová náročnost domácí př́ípravy;

- zábavnost“ výuky;

- rychlost zpětné vazby od pedagoga;

- $\quad$ využití připravených materiálů při samostudiu;

- zjednodušení formy prověřování vědomostí a dovedností;

- soukromí při prověřování dovedností a znalostí (eliminace trémy při přezkušování před kolektivem tř́́dy);

- $\quad$ schopnost účasti na př́pravě cvičných testů.

2) spokojenost s výukou s využitím IT pohledem učitele

Výzkum v této rovině je realizován analogicky s rovinou předchozí, s akcentem na:

- náročnost př́pravy na danou výuku;

- možnosti testování výstupů z učení;

- $\quad$ aktivita a participace žáků;

- c časová úspora při vyhodnocování testů;

- časová dotace IT v průběhu vyučovací jednotky;

- možnost diferenciace žáků;

- individuální př́stup k žákovi.

\section{Závěr}

Výsledky dokončené části výzkumu ve většině korespondují se stanovenými hypotézami. Jestliže se smysluplně použijí prvky ICT ve výuce hudební výchovy, výuka se pro žáky stane atraktivnější a zároveň zvýší participaci žáků ve vyučovací hodině. Tímto způsobem lze zvýšit žákovskou úspěšnost při testování a povzbudit jejich vzájemnou kooperaci. Pozorování chování žáků při pilotní výuce potvrzuje zvýšený zájem a aktivitu žáků při všech výše zmíněných hudebních činnostech a totéž lze vyvodit i z odpovědí žáků v dotaznících zkoumajících spokojenost s novým postupem výuky. Využití ICT při evaluaci vědomostí se jeví jako vhodná alternativa jindy nepopulární činnosti. Žáci dokonce vyžadovali častější testování tímto způsobem. Toto u tradiční verze ověřování vědomostí (písemné práce) nelze očekávat.

Záznam hudebních činností pomocí ICT a užití QR kódů v pracovních listech dává možnost změny edukačního prostředí $\mathrm{v}$ prostředí podporující vyšší participaci žáků na výuce, také dává možnost úspěšného zvládnutí či pochopení zadaného úkolu. 
Nevýhodou učitelů hudební výchovy, jak plyne z úvodního výzkumu je, že jejich předmět není preferován a vybavenost učeben prvky ICT je slabá. Práce se zmíněnými technologiemi je žákům a studentům blízká, a proto se nabízí využití vlastních mobilních zařízení žáků během výuky. Zvýšená míra použití ICT při plnění studijních povinností by mohla vést $\mathrm{k}$ aktivizaci studentské či žákovské kooperace, ke zvýšené participaci žáků ve vyučovacím procesu, $\mathrm{k}$ lepším žákovským výkonům, k posílení studijních i komunikačních kompetencí žáků a v neposlední řadě ke zvýšení atraktivity vzdělávacího procesu HV. Dříve zmíněné hypotézy se nyní $\mathrm{v}$ závěrečné fázi výzkumu ověrují v dalších tř́idách i školách. Pokračovat bude i hledání dalších cest implementace ICT do výuky HV, které podpoří zkvalitnění a modernizaci její výuky.

\section{Literatura}

Bertrand, Y. (1998). Soudobé teorie vzdělávání. Přeložil O. Selucký. Praha: Portál.

Brezinka, W. (1996). Filozofické základy výchovy. Přeložil I. Ozarčuk. Praha: Zvon, české katolické nakladatelství.

Dušek, B. (1982). Psychologie hudby. Praha: SPN.

Franěk, M. Hudebni psychologie. (2005) Praha: Univerzita Karlova v Praze, nakladatelství Karolinum.

Grecmanová, H., \& Urbanovská E. (2007). Aktivizačni metody ve výuce, prostředek ŠVP. Olomouc: Hanex.

Herden, J. (1994). My pozor dáme a posloucháme: posloucháme hudbu se žáky 1. stupně základni školy. Praha: Sciencia.

Herden, J. (1997). My pozor dáme a nejen posloucháme: posloucháme hudbu se žáky 2. stupně ZŠ a nižšich ročnikù osmiletých gymnázii. Praha: Scientia.

Holas, M. (2004). Hudební pedagogika. 1. vyd. Praha: Nakladatelství AMU.

Kolář, Z., \& Vališová, A. (2009). Analýza vyučování. Praha: Grada.

Luska, J. (2006). Vybrané otázky srovnávací hudební pedagogiky. In Hudebni věda a výchova 10 (83- 88). Olomouc: Univerzita Palackého.

Musil, O. (2015). Multimediální výuka hudební výchovy. Nepublikovaná diplomová práce.

Brno: Masarykova univerzita.

Průcha, J. (1997). Moderní pedagogika. Praha: Portál.

Poledňák, I. (2005). Hudebně pedagogické invence. Praha: Univerzita Karlova.

Sedlák, F. et al. (1984). Didaktika hudební výchovy na II. stupni ZŠ. Praha: SPN, publikace č. 16- $08-11 / 12$

Sedlák, F. (1990). Základy hudebni psychologie. Praha: SPN. Strouhal, M. (2013). Teorie výchovy: $k$ vybraným problémům a perspektivám jedné pedagogické discipliny. Praha: Grada.

Vávra, M. (2013). Aplikace hudebního softwaru Ableton Live v hudebni edukaci. Nepublikovaná disertační práce. Olomouc: Univerzita Palackého.

Waltová, M. (2004). Využití hudebního softwaru v didaktické praxi učitele hudební nauky. Nepublikovaná diplomová práce. Olomouc: Univerzita Palackého. 